\title{
PRACTICAL METHODS OF HOLDING AND PLAYING KARAKALPAK PEOPLE'S NATIONAL HORSE GAMES
}

\author{
Shilmanov Raxat Perdebaevich \\ Nukus State Pedagogical Institute, Candidate of Science of Physical Culture, Professor
}

Article DOI: https://doi.org/10.36713/epra9536

DOI No: 10.36713/epra9536

\begin{abstract}
The article describes Karakalpak people's national horse games as the important kind of sports which play a significant role in the upbringing young generation in physically strong state and developing their future intelligence. The article deals with explaining practical methods of holding and playing our national horse games and circumstances how they had been developed historically and reached our times. The classification of Karakalpak national horse games are based on customs, traditions and rituals of our ancestors established during the long period of their existence and cultural developing. In the paper, we have analyzed about twenty kinds of national horse games played as a sport at various folk family celebrations and public holidays. The paper states that some kinds of horse sport, for instance, as hunting on horseback with birds of prey (eagles, falcons) had been occurred as vital needs of our earlier ancestors. Horse games as a sport have been developed with the appearance of tribal communities, social groups of people, khanates and whole nation.
\end{abstract}

KEY WORDS: national horse games, sports, family celebrations, public holidays, kokmar (stuffed sheep - ilaq), horse racing, cantering race, horse breeding.

\section{INTRODUCTION}

Nowadays, before us there put an important goal to rise the popularity of horse sport games all over the republic both among the youth and adults for forming the healthy way of life everywhere. This duty of our people has been steadied by the government of our country and the desire of young people to go in for this type of sports is rising day by day. Our youth is very impressed by the facts of opening of horse sport (schools) manages, where our youth are trained to higher horsemanship skills under the guidance of experienced specialists. We believe our youth will actively go in for this type of sports and become winners of international contents on these kinds of horse sports, being rewarded with the highest praises and titles.

In the life of the Karakalpak people's horse games have been played as a sport beginning from ancient times. In ceremonies on occasions of family celebrations (wedding, sunnet toy feasts) and public holidays (Nawruz, Harvest holidays) Our ancestors used to hold the earliest forms of horse games as at shabis /jarisi/ horse racing; jorga surispek/ contest on riding a horse in the even pace (cantering), ilaq. Periods having passed and reached our days kinds of our national horse games have been enriched both in quantity (with new types) and in quality (they were played fairly with new standard rules). Nowadays horse games including their types of ilaq oyini (Ilaq oyini - a sport game played riding on a horseback in two or three teams in which teams fight against each other to win the kokmar (kokpar) (a stuffed sheep (young foal) seized between the feet of the rider/opponent and his stirrup (P. Sh. The author), alaman baygi (Alaman baygi - a contest on horse racing held in a number of groups of participants representing all the local tribes and neighboring countries. Nowadays the contest is called as "Horse reacing maratho), (horse racing marathon) jorga jaris (jorga surispek (Eng: cantering)), at omirawlastiriw, (horse wrestling) attan awdarispaq (wrestling on horseback), qiz quwiw, gumis aliw, tay jaris, at sekirtiw, at arba aydaw jarislari and other types of Karakalpak people's national horse games are renewed and played at ceremonies on occasions of family and public holidays as wedding and sunnet toy feasts. Nawruz, Harvest holidays and Independence Day. Besides, the list of horse games has been filled with one another type, girls' horse riding.

Our government pays a new attention to further development of national horse games as one of the popular type of sports. There was adopted the Decree of the President of the Republic of Uzbekistan "On the further development of Horse breeding and Horse sports in the Republic of Uzbekistan" from the $18^{\text {th }}$ of February 2019, which was followed by the organizing of the "Federation of the Horse breeding and Horse sports of the Republic of Uzbekistan" [1]. There were put forward before us an important task of further developing horse breeding and horse sports, taking the youth for going in for these kinds of sports, propagandizing a healthy way of life and also achieving higher results in national and international contests on all types of horse sports.

People's national sports games bring up our citizens to cheerfulness, cleverness, artfulness, tolerance, 
quickwitedness, activeness and powerfulness. There was no ceremony among karakalpak people held without national games. Before beginning of people's sports games on feast days there are held festive gatherings in the open streets and squares on public holidays with a high joy and cheerfulness including dances and songs in baqsis (A baqsi - a national performer of folk eposes and songs in his/her own accompaniment on the national two - stringed musical instrument - duwtar) and jiraw's (A jiraw - a national performer of folk eposes and songs in his/her own accompaniment on the national musical instrument with strings called qobiz, played with a bow) performing in duwtar and qobiz contests between maidens and young people in singing or inventing rhymes or verse lines humorously for fun, playing in national musical instruments as shinqobiz, balaman and other kinds of wind. The ceremonies are held in high spirits with enthusiasm.

\section{METHODOLOGY}

According to a number of scientific - methodological works, pedagogical researches and points of views occurred after disputes among scholars and specialists one can have conceptions on the denominations of the horse sports games given below. Due to their rules of playing and meaning horse sports games are introduced in the following types (kinds):

1. Kokpar (ilaq oyin) (a horse sports game for winning Kokpar)

2. Atti baygige jiberiw (Horse racing)

3. Qiz quwiw (Chasing after a girl on horseback)

4. Attan awdarispaq (wrestling on a horseback)

5. Attan nayza ilaqtiriw (throwing a spear from horseback)

6. At ustinde qilishlasiw (Fencing on horseback)

7. At ustinde oqjaydan atisiw (shooting an arrow from bow on a horseback)

8. Jorga jaris (jorga surispek) (Contest on riding a horse in the cantering pace

9. Alaman baygi (horse racing marathon) a multi grouped horse race with participants from everywhere)

10. Qizlardin at shabis jarisi (Girls' horse racing)

11. Gumis aliw (taking out a bundle with jewels in it from the surface of land cantering on a back of horse

12. At omirawinan aylaniw (making rounds round the neck of the horse while galloping)

13. Tay jarisi (Horse racing on a back of colt)

14. At omirawlastiriw (Making horses push each other with their chests until one of them move behind or aside or fall)

15. At sekirtiw (making a horse jump out barriers)

16. At seyislew (training a racing horse)

17. Burkit saliw (Hunting on a horseback with eagle)

18. At arba jarisi (carriage race)

19. Qanjiga qizartiw (riding on horseback together with a girl behind)

20. At ustinen doyir uriw (making guys fall down dealing a blow with cudgel from a back of a galloping horse).

Originally according to their types and importance the above mentioned games are considered very significant ones in further developing and everlasting our national mentality as they require from individual being always active. Besides, a horseman (horse racer) should be a strong, highly skilled, clever, crafty, cunning and tolerant enthusiast. At present period of cultural and global cultural development young people must be fairly informed and thoroughly aware of our popular national horse sports games as ilaq (kokmar), horse racing and etc. Above all, this is one of the most important tasks put forward before our youth. The youth of our country all should deeply feel it as their civic moral duty. Saying with the folk language "people's national games" are held and played at a place where a huge crowd of people is gathered where one can believe that there is holding a real nation - wide festive celebration. Thousands of people watch the games and evaluate them. Horsemen receive their awards according to their results and places achieved at the games. From the side all this can be seen as a very simple sight, however, it rises the consciousness of the youth and motivate them to go in for such activities with a high creativity eagerly looking forward for becoming all - round mature and sound both knowledgeably and culturally. People's national horse games not only a test for determining how the horsemen are strong and behave, but they are an enormous part of the spiritual values of our nation that allow young people to understand the customs of their grand - grandparents and bear a great upbringing significance. At the same time national horse games had been functioned as one of the kinds of military methods, which required a great quickwitedness and cunning of a cavalryman.

\section{RESULTS AND DISCUSSION}

Below, we introduce how the games are played nowadays:

Ilaq oyin in the past the game was played with the participation of two, three and more teams. Every team consisted of $3-10$ most skilled horsemen representing their communities, for instance, as "Irg'aqli awildin shabandozlari"/"Horsemen from the village of Irg'aqli" "Kholdawlinin jigitler"/"Representatives from Qoldawli" Shakhamannin shabandozlari"/"Horsemen from Shajh-aman", Alimbet - Da'w topari"/"The team of Alimbet - Da'w" "Arzi Ataliqtin jigitleri"/Arzi Ataliks's Men" and etc. if there were horsemen representing neighboring countries, they were allowed to form their own team, having agreed with game holders. Nowadays ilaq oyin is played between two teams each consisted of $8-10$ members at the age of $18-35$, who can cope with all the rules and methods of horsemanship. The place where the game is held must be chosen in the area outside the city or town (centre), where the surface of land is level and not very stony for not hurting horses' feet. The length of the square is equal to $300-400$ meters and the width $-150-200$ meters. And in the centre of the square there is a circle with diameter of 9 meters. Teams' members greet each other on horseback round the circle standing in opposite sides. Team leaders with the Head Referee draw lots to decide two players to begin the content. Then two representatives from the teams fight against each other to take out Kokmar from the surface of land first. The horseman who takes out of the sunface of land the ko'kmar gallops away on horseback trying 
not to give back the ko'kmar to their opponents and return it under the defence of his teammates and throw into the circle in front of adjudicators. The head reference record the first point into the account of the player who opened the scoring. In circumstances a horseman can pass the ko'kmar to one of his teammates. The play continues familiarly to the above mentioned tactics. Both teams showed struggle for best opportunities for holding a victory. However trying to seize the ko'kmar a horseman shouldn't display a coarseness hitting his opponent or shouting nonsenses, unless referees instantly fine him or remove him from playing. The team which throws the ko'kmar more times into the circle in front of the stand of the body of adjudicators. The weight of ko'kmar mustn't increase 15-24 kilogram. The content lasts an hour or two. After finishing the game the results are summed up and the winners are awarded.

Qiz quwiw. (Running after a horsegirl on horseback) The game is popular among the young people. It is one of the national horse games played as sport with the participation of a girl who is good at horsemanship and young fellow of the age of 17 who is also a skillful horse-rider. The play is popular among people of Middle Asia. Girl horse rider's age must be 16 years old and can be exceeded to some 2 or 3 years.

The game of Qiz quwiw is held a remote place outside the city (town, village) where the land is level or in the special place race-course. The distance of the race mustn't exceed 1000 (thousand) meters. A young horseman stand at the start line but the girl rider is allowed to start her racing from 25 th meters. (The start line is considered zero point). The goal of the game: a young man in the racing must catch up with the girl before she passes the finish line he is considered a winner, if not, a failed one. If the contest is held among teams the team with more scores is a winner. If girls believe that they can cope with the matter, they can also form the own teams against young horsemen.

Atti baygige jiberiw. Horse racing. Horse racing is one of the most popular types of Karakalpak national horse sport. Contests are held on wedding ceremonies, at sunnet toy feasts and public holidays as Nawriz, Independence day and at a particular ceremonies held on the occasions of jubilees and anniversaries of public figures (People's Heroes, Honoured Artist, Meritorous Sportsman of our people etc.) and Harvest Holiday etc. In this contest there are tested and chosen the fastest and strongest horses and the most skillfull horseriders. Horse-breeders present their best horses and their youngest riders acquiring with higher skills of horsemanship in horseracing there must be involved youngest quick-witted riders in real sports manner. So to horseracing competitions must be sent per a horse by each horse breeder. They sent their own horses which are prepared and thought in advance by their riders both physically and accordingly to requirements of sports competition.

The distance of the racing track must be equal to 8-10 $\mathrm{km}$ (for youngsters) (14-16 aged) and 10-16 km for adults (2735 years old).The successful participants are rewarded due to their results by adjudicators. The holders of the first, second and third places are awarded with golden, silver, bronze medals the rest activists with certificates for ten tops and praise lists. The types of horse games as Wrestling in horseback, Throwing a spear from horseback, fencing on horseback, shooting an arrow from a bow on horseback (at omirawlastiriw) making horse to push each other with their chest until one of them move away or fall making guys fall with a blow of a cudgel from horseback are usually held at celebrating the Day of Defendens of Motherland the Cavalry Day and etc. Besides making rounds round the neck of the horse while galloping belong and familiar to the abovementioned types.

Jorga jaris. Contest on riding a horse in cantering pace. The competition is held with the participation of horsemen and horsewomen of the age 16 and older. The distance for women is $2-3 \mathrm{~km}$ and for horsemen is $8-10 \mathrm{~km}$. The cantering horse's age mustn't be younger than 3 years. The riders compete by two or four horse racers. In the contest the main index is time at which every horseman reached the finish. Horsemen and horsewomen shouldn't break the pace of santering while they ride towards the finish. It's not allowed to lash the cantering horse and make it gallop. If a horseman/horsewoman makes the horse break it's santering pace two times within $2 \mathrm{~km}, 5$ times within $4 \mathrm{~km}, 6$ or 7 times within $6 \mathrm{~km}$ and $8-10$ times within $10 \mathrm{~km}$ the horseman/horsewoman is debarred from participating in the content the winners are rewarded with prizes offered by the host of the celebrity on the organizers of the competition.

Alaman baygi (horse racing marathon). A multigrouped horse-racing with participants from everywhere. A multi-grouped horse racing is held in cases when the number of participants exceeds some 40 or more horsemen and they have opportunities to form teams by themselves. The horses and horsemen participating in this type of horse racing can be represented from various teams, each team can represent per 6-7 horsemen. All the horsemen and horses are registered in advance by adjudicators. The distance from start to finish shouldn't exceed $16 \mathrm{~km}$. Besides, there are distances which are equal to $7-12 \mathrm{~km}$. The youngest member of the team can be 18 years old. In competitions teams bear their own emblems. The horse's ages ranges from 5 to 7 . It's forbidden to gallop along a straight path in order to cheat other horsemen. The race should be held on the specially arranged level place or on the race-course. The results of teams are summed up by times of their members' reaching the finish line, recorded by referees. When two horse race in parallel pace the horse which passed the finish with its head stretched forward is considered a winner.

Girls' horse racing. Only girls of the age of 14-17 participate in this types of racing. The difference of this racing is in the shorness of the distance of the track. It's equal to 2-3 $\mathrm{km}$. The rules are the same with other types of racings.

Attan awdarispaq. (making gays fall down with dealing a blow with while galloping on horseback) / Wrestling on horseback. In this kind of horse sport two horsemen on horseback try to make each other fall out of the back of the horse by the strength of their hands steadily holding on horseback with their legs.

Gumis aliw. Taking a bundle with jewels in it out of the surface of land on a back of cantering horse. In this kind 
of Horse sport horse-men compete in taking a bundle with jewels in it out of the surface of land riding on a back of cantering horse. The distance from the start line until the finish line is 100 meters. On the $50^{\text {th }}$ or $60^{\text {th }}$ meter of the track there put a white flag on the top of pole with lower and spread deeply onto the land and aside of the pole is placed a bundle with jewels in it. Horsemen / horsewomen participating in the contest compete in turns cantering on horseback and trying to take the bundle out of the surface of land in the cantering piece. Competitors are given per three attempts, when they are individual participators. In the competition between teams attempts are not given. The individual competitor who takes the bundle in the first attempt wins the first prize, who copes with the task second wins the $2^{\text {nd }}$ prize and if it turns out well for the third time he/she will win the third award. If the board of adjudicators agree attempts can be considered as rounds, so in this case the one who achieves scores in all the three rounds becomes a pure winner who will be awarded with a super prize. The reset shares the second and third prizes according to their results. All the results are defined due to the referees' reports. The places between teams are shared by the sum of scores, achieved by their members.

Bu'rkit saliw. Hunting on horseback with eagle. This type of sport began from prehistory period not as sport but it had been used as the way of earning their need for food and dress. Milleniums passing after the occurrence of social groups, scribal communities, kingdoms, khanates, nations, etc, there appeared the mentioned types of horse sport for instance in some folk tales it is read as: "At that moment a Khan and his men were out hunting with his eagle and falcons. Suddenly, a gazelle run out before the King, he set his eagle after the gazelle, but the eagle, instead of chasing after rose high into the sky and swooped down... when the Khan and his men reached the place ... they saw the most beautiful girl in the world had ever seen lying on the ground unconscious. The eagle was sitting near the head of the girl" [2, 91-92] or “... I am not here by chance, nor I'm here on a special visit to you, my shepheads" said Gu'lziba. "I was hunting with my forty men and we run into a deer. I started to chase the deer alone and lost my forty men. If any of you helps me to join the forty men I'll give 1000 gold coins in reward, including my second horse" [2, 223].

This kind of horse sports is held only for entertainment between a group of themselves without pans as the sport requires natural circumstances. Eventually the galpes can present their tame birds of prey among spectacles on Harvest holidays and other public holidays. Only as highly skilled galpes (trainers of tamed birds of prey) can demonstrate their art completely (with making their tame bird make hunting the pray suddenly freed out of their shirt or cage.

The organizers (holders) of the content and the adjudicators board (the Chairman of the A.B., the chief referee, a doctor, a veterinary and secretary) are responsible for holding the contest without any extraordinary cases. The participants are divided into following weight categories:

1. Horsemen of light weight category up to $60 \mathrm{~kg}$

2. Horsemen of light weight category up to $70 \mathrm{~kg}$
3. Horsemen of average weight category up to $80 \mathrm{~kg}$

4. Horsemen of high weight category exceeding $80 \mathrm{~kg}$.

The competition begins with the signal of chief referee and going. It is ended also by going. Wrestling on horseback lasts 20 minutes. If nobody can achieve a decisive victory within these 20 minutes, the narrow victory is given to the horseman who has scored a bit more. The wrestling is held inside of the circle with 9 metres diameter in front of the stand of the board adjudicators. The horsemen shouldn't cross out the circle line. If one of wrestlers is lightly wounded or sports from has become not fit for a moment the wrestling should be stopped for 5 minutes and in five minutes the one who has given a break can cope with opportunity and continue the struggle he is considered failed.

\section{CONCLUSION}

Thus, to conclude, having got encouraged by the above mentioned genius of our ancestors the time to achieve popularity of sport, including especially horse games that have been experiencing a period of stagnation in our Republic. In order to achieve this goal we should buy brood mares from neighbor countries and abroad and breed them for this important purpose and open horse sports schools, manages where young horsemen are trained to higher horsemanship skills under the experienced specialists. As the horse games had been inherited from our earlier ancestors the games mustn't only played among us in our family celebrations or public holidays, we, our people and authorities must manage or our national horse games to join the list of games played in international competitions. People all over the world never refused from breeding horses and horse sports. Horse breeding is an important branch of economy in many countries of the world. Besides, horse-racing and other kinds of horse sports are developed and played in international countries. It has become one of the popular sports all over the world.

\section{REFERENCES}

1. Mirziyoyev Sh.M. "Decree on the Further Development Horsebreeding and horse sports in the Republic of Uzbekistan". Febuary 18. 2019.

2. Otegenov Q. The English Translation of the book Karakalpak folk tales. "Toronto" Canada 1995. pp. 91-97. 